DOI 10.17150/978-5-7253-3017-5.05

М.Д. КУШНАРЕВА

УДК 9(С18)17

ББК 63.3

ОСВОЕНИЕ РЕСУРСОВ ЗОЛОТА ФИРМОЙ «М.А. КОКОВИН И И.А. БАСОВ» В СЕВЕРО-ВОСТОЧНОЙ СИБИРИ В НАЧАЛЕ ХХ В. ПО МАТЕРИАЛАМ КУПЕЧЕСКОЙ ПЕРЕПИСКИ

В статье исследованы проблемы освоения ресурсов золота фрирмой «М.А. Коковин и И.А. Басов» на основании данных купеческой переписки. Анализ ранее не опубликованной и не введенной в научный оборот купеческой переписки представителей торгового дома «М.А. Коковин и И.А. Басов» позволяет исследовать особенности организации золото-разведочных работ на отдаленных территориях Северо-Восточной Сибири периода модернизации Российской экономики.

Ключевые слова: переписка, Северо-Восточная Сибирь, золото-разведка, торговый дом, купечество. 


\section{DEVELOPMENT OF GOLD RESOURCES OF THE FIRM «M.A. KOKOVIN AND I.A. BASOV» IN NORTH-EASTERN SIBERIA AT THE BEGINNING OF THE XX CENTURY ON MATERIALS OF THE MERCHANT CORRESPONDENCE}

The article explores the problems of the development of gold resources by «M.A. Kokovin and I.A. Basov» based on data from merchant correspondence. Analysis of previously not published and not put into scientific circulation merchant correspondence of representatives of the trading house «MA. Kokovin and I.A. Basov» allows to explore the features of the organization of gold exploration in remote areas of North-East Siberia during the modernization of the Russian economy.

Keywords: correspondence, North-East Siberia, gold exploration, trading house, merchants.

На территории Северо-Восточной Сибири в начале XX в. представители предприятий с крупным капиталом занимались развитием торговли и снабжением населения края товарами потребления в экстремальных условиях Крайнего Севера. В настоящее время эпистолярное наследие, оставленное нам представителями фрирм с крупным капиталом, позволяет судить о масштабах их экономической деятельности на северо-востоке страны и решать многие вопросы современной жизни с учетом исторических традиций. Исследование и введение в научный оборот ранее не изученной купеческой переписки позволяет проанализировать процесс освоения фрирмами с крупным капиталом ресурсов золота, который тесно сочетался с торговой и другой производительной деятельностью предприятий.

Следует отметить, что эпистолярное наследие ранее уже привлекало внимание российских ученых. В 80-е гг. XX в. была издана переписка Г.Н. Потанина, состоявшая из 662 писем, 630 из которых ранее никогда не публиковались [12, с. 7]. С.Ф. Коваль отметил, что изучение эпистолярного наследия Г.Н. Потанина позволяет исследовать проблемы развития в Сибири политических сил и экономических процессов [2, с. 22]. В 2004 г. сотрудниками Томского государственного университета была осуществлена публикация более, чем 250-ти писем Г.Н. Потанина, хранившихся в научной библиотеке Томского университета [1, с. 3]. Широкий круг источников из цикла сибирской мемуаристки был введен в научный оборот Н.П. Матхановой. В сферу научных интересов автора вошли неопубликованные письма и воспоминания представителей сибирского купечества Н.Н. Пестерева и Прокопия Похолкова [4; 5]. Введение в на- 
учный оборот новых источников, относящихся к циклу эпистолярного наследия, позволило Н.П. Матхановой исследовать широкий круг проблем истории Сибири, а также заложить методологические основы анализа источниковых данных и их применения в разработке научных проблем.

Приведенный небольшой анализ работы исследователей с эпистолярным наследием деятелей изучаемой эпохи свидетельствует о значительных информативных возможностях этого вида источников как с точки зрения пониманиях поступков и взглядов отельных личностей, так и с позиции этапов фрормирования их мировоззрения в целом. В этом смысле думается, что обращение автора к изучению купеческой переписки позволит высветить новые грани деятельности представителей крупного капитала в Северо-Восточной Сибири.

Для изучения проблемы развития золотопромышленной деятельности предприятий с крупным капиталом важную роль играет купеческая переписка делового характера, относящаяся по своему происхождению к эпистолярному наследию. Основная ценность купеческой переписки, как источника по изучению проблемы деятельности фирм с крупным капиталом в золотопромышленности заключается в том, что деловая переписка, во многих случаях, составляла основу коммерческого делопроизводства предприятий. К купеческой переписке относятся деловые письма распорядителей торговых домов и их приказчиков, телеграммы, письма-отчеты и многое другое.

Целью данной публикации является анализ процесса освоения ресурсов золота фирмой «М.А. Коковин и И.А. Басов» в Северо-Восточной Сибири в период модернизации российской экономики на основании материалов купеческой переписки.

Торговый дом «М.А. Коковин и И.А. Басов» был зарегистрирован в 1885 г. в Кяхте и специализировался на торговле чаем и другими колониальными товарами. Одной из сфер применения капитала товарищества была добыча золота и торговля на приисках, главным образом, чаем [15, с. 324]. В 1900 г. главная контора торгового дома «М.А. Коковин и И.А. Басов» была перенесена в Москву. В 1903 г. было открыто Якутское отделение фрирмы для организации торговли в северных округах Якутской области и на Чукотке. Основной капитал торгового дома «М.А. Коковин и И.А. Басов» в 1905 г. составлял 500 тыс. руб. Товарищеские вклады М.А. Коковина и И.А. Басова составляли 250 тыс. руб. каждый. Главным распорядителем фирмы являлся М. А. Коковин [7, л. 1-21].

По данным Якутского областного статистического комитета, разработка месторождений золота фирмами с крупным капиталом велась в районе р. Алдан с 70-х гг. XIX в. [6, л. 117]. Основные ресурсы золота в Северо-Восточной Сибири были сконцентрированы в районе Ленско-Витимского и Олекминского бассейнов [13, с. 102-114]. В конце XIX в. фир- 
ма «М.А. Коковин и И.А. Басов» занималась освоением золотоносных месторождений на р. Витиме в районе Бодайбинской резиденции. Компания владела золотыми приисками в Забайкалье [14, с. 62]. В конце $\mathrm{XIX}$ - начале XX вв. на средства торгового дома «М.А. Коковин и И.А. Басов» начинается разведка и добыча золота в бассейне р. Колымы [8, л. 1-16]. Основные сведения о процессе развития золото-разведки фрирмой «М.А. Коковин и И.А. Басов» на северо-востоке Сибири содержатся в переписке якутского купца 2-й гильдии В.И. Фефилова.

Василий Иванович Фефилов являлся уроженцем Якутской области, на службу в фрирму «М.А. Коковин и И.А. Басов» поступил в качестве приказчика в 90-х гг. XIX в. В.И. Фефилов ежегодно участвовал в Якутской, Анюйской, Нижегородской ярмарках, прекрасно разбирался в пушной, лесной торговле, горнорудном деле. С 1900 г. В.И. Фефилов был назначен доверенным лицом торгового дома «М.А. Коковин и И.А. Басов» в Колымское отделение [3, с. 49]. В 1905 г. В.И. Фефилов занимался развитием Охотского отделения фрирмы, в 1908-1917 гг. являлся доверенным лицом торгового дома в Аяне и Нелькане. В 1906 г. В.И. Фефилов получил купеческое свидетельство 2-й гильдии [10, л. 34].

В 1908 г. в главную контору торгового дома «М.А. Коковин и И.А. Басов» поступило одно из первых писем В.И. Фефилова о золото-разведочных работах, проводимых им в районе р. Алдомы. Приведем некоторые цитаты из письма В.И. Фефилова в главную контору торгового дома «М.А. Коковин и И.А. Басов». Итак, В.И. Фефилов писал: «Милостивые государи! К сведению Вашему сообщаю, что есть еще интересное место недалеко от Аяна и в 15 верстах от Алдомы. Я прилагаю чертеж наскоро, чтобы Вам удобно было понять, где эта местность. Дальше Улкана Богданович заметил проходом из Охотска в одной соседней речке золото, оставил там провизию, но не успел разведать, уехал, а провизия там осталась. Обо всем расскажет Вам Попов А. Ф.В. Фефилов» [11, л. 14 об., 15].

В 1908 г. другим доверенным лицом фирмы «Коковин и Басов» А.Ф. Поповым в Горное Управление были поданы заявки на разработку золотых россыпей, расположенных по течению р. Алдомы [9, л. 14]. Однако в этом году А.Ф. Попову было отказано в открытии разведочных работ, что было связано с ненадлежащим оформлением документов. Об этом В.И. Фефилов написал в своем письме в Якутскую контору торгового дома «М.А. Коковин и И.А. Басов» в своем письме от 14 ноября 1908 г. Кроме того, Фефилов в письме достаточно подробно описал ход дел на золотых промыслах в районе реки Алдомы: «Милостивые государи! Относительно заявления приисков А.Ф. Попову отказали, так как он выставил статьи Устава, отмененные новым Уставом 1903 года. Он на несколько площадей подал одно заявление, а по новому Уставу по 20, 23 и 29-й 
статье положено на каждую площадь особое заявление. Ему послали Устав 1883 г., который изменен. Остальные площади содержат гнездовое золото, которое для хозяйственных работ невыгодно. Жалеть особенно нечего. Фризерские на приисках оставили караульного бесплатно с правом мыть золото. Этот караульный моет золото на Бутарне, чего до отвода площади не допускается. За это Фризера могут лишить права золотопромышленности и это золото должно поступить в казну. Свободно можно отнять эту площадь от Фризера, он как видно совсем уехал, все продал, так же и Ельцовские. Товары и припас купили Цветков, Филиппов и урядник. Начиная с Алдомы до Аяна ни одного ключика нет свободного, все занято. Стоят столбы, Фризера, Ельцовых, Кушнарева с Филипповым, Поповых Федора и Владимира, Стрелова, Юшманова, Богачевского. По крайней мере, 300 площадей, а заявленных едва ли найдется до 50-ти, остальные все наобум и теперь почти все можно вновь занимать. Есть хорошие площади и занятые Владимиром Поповым. Работают хищники втихомолку, о чем А.Ф. Попов умалчивает, а Владимир Попов больше сюда едва ли явится. Он уехал на прииски на Витим. Обо всем надо бы справиться в Николаевске у инженера. В. Фефилов» [11, л. 15, 15 об.]. В том же 1908 г. В.И. Фефиловым была составлена подробная карта золотоносных площадей в районе р. Алдомы [9, л. 22].

О результатах работ по разведке золота в районе р. Алдомы В.И. Фефилов написал в Якутскую контору торгового дома «М.А. Коковин и И.А. Басов» 7 декабря 1908 г. «Милостивые государи! Вчера я возвратился с Алдомы. Дорога сходится с Аянской в 55 верстах от Нелькана на р. Кыра. Тунгус, который меня возил, ездил с Богдановичем, рассказывает, что Богданович дальше Эйкана в одной речке нашел золото. При нем промывал и нашел золото там. Богданович оставил провизию. Но зимой очень трудный путь и ехать нужно летом на конях. Зимой на нартах трудно проехать с Улкана хребет сильно крутой. Зимой с Нелькана по Мае реке близко. С совершенным почтением честь имею быть Вашим покорным слугой В. Фефилов» [11, л. 20 об. - 23].

В конце 1908 г. В.И. Фефилов написал еще одно письмо в Якутскую контору торгового дома «М.А. Коковин и И.А. Басов». В письме от 12 декабря 1908 г. В.И. Фефилов подробно описал обстоятельства, которые появились при организации освоения золотоносных месторождений в долине р. Алдомы. «Милостивые государи! Вчера приходил ко мне Карачев, который путешествует по приискам. В прошлом году он приехал сюда с Ельцовскими и весною выехал во Владивосток, но во Владивостоке его остановил доверенный Фризера, кажется Риф, уговорил его возвратиться обратно в Аян. Этот Карачев приехал обратно осенью на пароходе с товарищем, которого он называет учеником. Он проживает у Фризера на прииске, сюда в Аян приехал он за провизией, которая им 
привезена на пароходе. Он привозил с собою золото, но продать не мог, денег ни у кого не оказалось. Мне предлагал 1,5 фунта. Ко мне он зашел с просьбой рекомендовать его к «Ленскому Товариществу». Полез в карман и достал из мешочка самородок в 3,5 золотника и дает в подарок, но я отказался. Я спросил Карачева, если бы я пошел искать золото, то ты пошел бы или нет со мной? Он сказал, мне: «с великим удовольствием, только вместе с товарищем», и уверяет меня, что есть уже золото в пол золотника содержания. Но богатства здесь пока не видно и говорит, что пески только две четверти. Еще знаю, 3 площади должно быть порядочно золота. Но я не разведывал, собираюсь делать разведку. Карачев говорит, что есть золото, только надо искать не в руслах речек, а в горе, то есть в свалах гор и за тем он тоже подтверждает, что где-то хищники татары работали, много золота намыли. Если бы были лошади, да провизии, то можно бы попробовать поискать в 80 верстах отсюда. Карачев тоже советует тут искать. Сейчас места заняты Фризерскими, от них был шурф. Сын Попова А.Ф. нашел самородок в 1,5 фунта, начал бить второй шурф, и не дали окончить, рабочие забастовали, и было уже поздно. Теперь он надежду на Фризера и Ельцова потерял, ужасное желание высказывает мне в поиске золота, главное предупреждает, что дорого не возьму, даже божится, что подводить Вас не буду к крупным расходам. С совершенным почтением имею честь быть Вашим покорным слугой В. Фефилов» [11, л. 23-17].

Следующее письмо В.И. Фефилова в Якутскую контору фрирмы «М.А. Коковин и И.А. Басов» было написано 17 января 1909 г. В нем также содержалась информация о проведении разведочных работ. «Милостивые государи! В случае, если будете посылать мне доверенности на поиски золота, наведите справки от Стрелова и от Фризера, будут ли они работать здесь и возможно ли занять некоторые площади (разумеется, не от них лично). Я боюсь, что бы, не застолбить чужую площадь, и не получились бы неприятности. Я теперь знаю две площади, где, безусловно, есть золото. Хищники работают, только вода не допускает и вообще до почвы никто не добивал шурфы. Затем вышлите самый последний Устав золотопромышленности с последними дополнениями и руководство разных заявлений по золотопромышленности. С совершенным почтением имею честь быть Вашим покорным слугой В. Фефилов» [11, л. 30-31 об.].

Ответ на отправленные в Якутскую контору письма В.И. Фефилов получил в марте 1909 г. Распорядители торгового дома «М.А. Коковин и И.А. Басов» указали на необходимость осваивать золотоносные месторождения в долине р. Алдомы. Весной 1909 г. В.И. Фефилов начал работы по разведке месторождений, о чем написал в Якутскую контору торгового дома 30 марта 1909 г.: «Милостивые государи! Честь имею 
уведомить Вас, что письмо с двумя доверенностями и свидетельствами на право поисков золота от имени Михаила и Федора Михайловичей Коковиных и деньги имел честь получить. Теперь я получил доверенности на поиски золота, но вблизи Аяна все кругом занято, везде столбы стоят. Боюсь, как бы ни нарваться на чужие заявки, и затягивать долго нельзя. Как видно, показалось золотишко на 12 саженях глубины. Бур работает хорошо. Я писал Вам, что Богдановичем найдено золото и была оставлена провизия от Аяна в 250 верстах. Там никто еще не заявлял. Мне крайне желательно посмотреть это место и опытный человек есть у меня, о котором я писал. Он соглашается поехать. Но эта поездка сопряжена будет с расходами не менее 300 руб. нужно спирту и лошадей. Прошу Вас ассигновать мне определенную небольшую сумму на этот предмет. Я зря никуда не поеду, и зря заявок делать не буду. Об этом мне сообщите через Охотск. С совершенным почтением имею честь быть Вашим покорным слугой В. Фефилов» [11, л. 38-40].

В апреле 1909 г. В.И. Фефилов выехал в Нелькан с целью отправки своей корреспонденции и получения писем-распоряжений из Якутской конторы фрирмы. В его письме, отправленном в Якутскую контору торгового дома «М.А. Коковин и И.А. Басов» содержались сведения о новой поездке к золотоносным участкам в районе Аяна. Приведем небольшую цитату из его письма: «Милостивые государи! В июне месяце я предполагаю поехать посмотреть место, где Богданович оставил провизию. Надо успеть до Опрокиднева, так как он непременно хочет туда ехать летом и прибудет на пароходе в Аян, а за тем отправится берегом до Охотска и оттуда попадет в верховья Маи до Нелькана. Это я верно знаю. По приезду в Аян я буду подряжать тунгуса на оленях. Опрокиднев меня допытывал об этом, но я отозвался тем, что мне не ассигновано средств на этот предмет. Вы об этом ему ничего пока не сообщайте, так как я и сам сомневаюсь в этой поездке. В крайнем случае, отправлю сына А.Ф. Попова с приискателем Карачевым застолбить эту местность, а осенью могу ехать сам. Желаю оставить столбы на этом месте. По карте Богдановича указано золото. Мне крайне необходимо иметь «Амурские ведомости» за 1909 год, потому, что там печатают какие заявки в Аяне отошли в казну, так как все заявки и ключи застолблены. Вновь занимать опасно, поэтому Опрокиднев хочет поехать в Николаевск, забрать точные справки и приехать в Аян на пароходе, а упоминаемая мною местность по берегу Охотского моря пока ни кем не занята. Туда еще приискатели не проникали и там не одна речка, а несколько. С coвершенным почтением имею честь быть Вашим покорным слугою. В. Фефилов» [11, л. 42-43].

Деятельность В.И. Фефилова по поиску и разведке золотоносных месторождений в районе р. Алдомы и Аяна продолжалась в период 
1909-1913 гг. Однако других писем, содержащих описание разведочных работ, не сохранилось. Известно, что разведка и добыча золота в районе Колымы торговым домом «М.А. Коковин и И.А. Басов» шла достаточно интенсивными темпами.

В заключении отметим, что исследование купеческой переписки представителей торгового дома «М.А. Коковин и И.А. Басов», позволяет осветить широкий спектр проблем организации золото-разведочной деятельности предприятия в Северо-Восточной Сибири в начале XX в.

Не смотря на тяжелые условия труда и жизни, за период 1908-1909 гг. В.И. Фефиловым было заключено более 20 контрактов с подрядчиками на организацию золото-разведочных работ. При этом, степень достоверности данных купеческой переписки достаточно высока. Для нас было важно рассмотреть эпистолярное наследие сибирских предпринимателей с точки зрения субъективности, сохранить детали, описанные в письмах, передать настроение, стиль и образ мыслей авторов посланий.

\section{Список использованной литературы и источников}

1. Есипова Н. А. Эпистолярное наследие великого сибиряка / Н. А. Есипова, В. П. Зиновьев, Г. И. Колосова // Потанин Г. Н. «Мне хочется служить Вам, одеть Вас своей любовью». Переписка. - Томск : Изд-во ТГУ, 2004. - С. 3-10.

2. Коваль С. Ф. Г.Н. Потанин - общественный и политический деятель / С. Ф. Коваль // Письма Г.Н. Потанина : В 5 т. - Т. 1. - Иркутск : Изд-во ИГУ, 1987. - C. 10-35.

3. Кушнарева М. Д. Пушная торговля в Северо-Восточной Сибири в переписке представителей фирм с крупным капиталом во второй половине XIX — начале XX вв. : монография / М. Д. Кушнарева. - Иркутск : Изд-во ИГУ, 2017. — 173 с.

4. Матханова Н. П. Сибирский купец Н.Н. Пестерев и его воспоминания (60-е гг. XIX в.) / Н. П. Матханова // Известия СО АН СССР. Серия «История, филология, философия». - Вып. 3.- Новосибирск, 1991. - С. 22-27.

5. Матханова Н. П. Купец Прокопий Похолков и его мемуары / Н. П. Матханова // Проблемы социально-экономического и культурного развития Сибири XVIIXX вв. : сб. науч. тр. / Под. ред. М. В. Шиловского. - Новосибирск, 2009. - С. $137-143$.

6. Национальный архив Республики Саха (Якутия) (НАРC (Я)). - Ф. 343 (Якутский областной статистический комитет). - Оп. 1. - Д. 211.

7. НAPC (Я). - Ф. 414 (Торговый дом «М.А. Коковин и И.А. Басов»). Оп. 1. - Д. 1.

8. $\operatorname{HAPC}$ (Я). - Ф. 414. - Оп. 1. - Д. 2.

9. $\mathrm{HAPC}$ (Я). - Ф. 414. - Оп. 1. - Д. 6.

10. $\operatorname{HAPC}$ (Я). - Ф. 414. - Оп. 1. - Д. 9.

11. $\operatorname{HAPC}$ (Я). — Ф. 414. - Оп. 1. — Д. 16. 
12. Письма Г. Н. Потанина / Сост. А. Г. Грумм-Гржимайло, С. Ф. Коваль, Я. Р. Кошелев, Н. Н. Яновский : В 5 т. - Т. 1. - Иркутск : Изд-во ИГУ, 1987. - 280 с.

13. Шиловский М. В. Основные вопросы природоохранной деятельности в дореволюционной Сибири / М.В.Шиловский // Опыт природопользования в Сибири в XIX-XX веках / Отв. ред. М. В. Шиловский. - Новосибирск : Изд-во Института истории СО РАН, 2001. - С. 102-114.

14. Энциклопедический словарь по истории купечества и коммерции Сибири : в 2-х т. - Т. 1 / Отв. ред. Д. Я. Резун. - Новосибирск : Академ. изд-во «Гео», 2012. $-450 \mathrm{c}$.

15. Энциклопедический словарь по истории купечества и коммерции Сибири : в 2-х т. - Т. 2 / Отв. ред. Д. Я. Резун. - Новосибирск : Академ. изд-во «Гео», 2013. -464 c.

\section{Информация об авторе}

Кушнарева Маргарита Дмитриевна - доктор исторических наук, доцент, кафедра сервиса и сервисных технологий, Иркутский государственный университет. 664003, г. Иркутск, ул. К. Маркса, 1, тел. 8(9021)705037, e-mail: rita270880@ mail.ru.

\section{Author}

Margarita D. Kushnareva - Doctor of Historical Sciences, Associate Professor, Chair of service and service technologies. Irkutsk State University, 664003, Irkutsk, Karl Marks st., phone 8(9021)705037, e-mail: rita270880@mail.ru. 